\title{
Rzeczywistość zapamiętana. Historia i pamięć Zagłady w prozie Piotra Pazińskiego
}

Kamil Nolbert

TEKSTY DRUGIE 2021, NR 3, S. 255-271

DOI: 10.18318/td.2021.3.17 | ORCID: 0000-0001-7206-030X

Na literacką twórczość Piotra Pazińskiego składają się dwie książki prozatorskie - debiutancka powieść Pensjonat ${ }^{1}$ oraz opublikowany w kilka lat później zbiór opowiadań Ptasie ulice ${ }^{2}$. Wydaje się, że najwięcej pożytku przynosi czytelnikowi wpisanie dzieł autora w nurt literatury postmemorialnej. Przede wszystkim dlatego, że podobnie jak w innych kojarzonych z nim utworach - Tworkach Marka Bieńczyka, Utworze o Matce i Ojczyźnie Bożeny Keff, Rodzinnej historii lęku Agaty Tuszyńskiej czy Kamieniu granicznym Piotra Matywieckiego - Pazińskiego zajmują głównie meandry polskiej pamięci związanej z doświadczeniami z czasów drugiej wojny światowej. W szczególności zaś wciąż konsekwentnie wypierana

\section{Kamil Nolbert}

- mgr, doktorant w Zakładzie Historii Literatury Polskiej po 1918 roku w IFP UWr. Naukowo zajmuje się poezją najnowszą, przygotowuje rozprawę o poetyckiej i krytycznoliterackiej twórczości Piotra Sommera. Kontakt: kamil.nolbert@gmail. com

1 P. Paziński Pensjonat, Nisza, Warszawa 2009. Wszystkie cytaty lokalizuję w tekście głównym, podając numer strony.

2 P. Paziński Ptasie ulice, Nisza, Warszawa 2013. Wszystkie cytaty lokalizuję w tekście głównym, podając tytuł opowiadania oraz numer strony. 
z oficjalnego obiegu pamięć o Zagładzie³ oraz żydowskiej tradycji przedwojennej Polski.

Paziński dobrze wie, że w jego sytuacji „,wchodzenie w buty Bogdana Wojdowskiego, Irit Amiel czy Michała Głowińskiego"4 byłoby zwyczajnie nie na miejscu, a etyczne wątpliwości potęguje niemożliwy do przekroczenia dystans czasowy i egzystencjalny. W jednym z wywiadów autor Pensjonatu podkreślał, że za wszelką cenę chciał uniknąć opowiadania o XX-wiecznej historii polskich Żydów z perspektywy ocaleńca, toteż jako pisarzowi trzeciego pokolenia po Holokauście pozostaje mu snuć „opowieść o żydowskim losie w cieniu Zagłady, o żydowskich wyborach"5.

Obecność historycznego i autobiograficznego tła wyraźnie zbliża Pazińskiego do innych urodzonych po wojnie autorów (nie tylko literackich) dzieł - by posłużyć się określeniem Christiana Boltanskiego - „mniej więcej o Holokauście":

Jeśli historia rodzinna - jak pisze Przemysław Czapliński - łączy ich z Zagładą, to w tym sensie, iż są dziećmi ocaleńców z Zagłady lub nawet dziećmi dzieci Zagłady: nie korzystają z własnych doświadczeń, lecz próbują uporać się z własną postpamięcią, a więc tym bagażem Holokaustu, który - mimo braku przeżyć - osadziła w indywidualnej pamięci kultura społeczna i komunikacja rodzinna. Są przesiąknięci Zagładą, choć nigdy się z nią nie zetknęli. Nigdy nie byli przez nią zagrożeni, a przecież w jakiś sposób się przed nią bronią. ${ }^{6}$

„Długi cień Zagłady” okrywa nie tylko tych, którzy cudem uszli cało, ale również kolejne pokolenia. Nawet jeśli w swojej prozie, raz po raz nawiedzanej

3 A. Mach Świadkowie świadectw. Postpamięć Zagłady w polskiej literaturze najnowszej, Wydawnictwo Naukowe UMK, Toruń 2016. Autorka monografii analizuje w swojej pracy m.in. utwory Pawła Huellego, Piotra Matywieckiego, Piotra Szewca, Bożeny Keff czy Agaty Tuszyńskiej. Dla prozy Pazińskiego, co ciekawe, nie znajduje miejsca, chociaż bez wątpienia jest on „świadkiem świadectw". W czasie pisania niniejszego szkicu powstawał artykuł Małgorzaty Golik, w którym autorka stara się umieścić utwory Pazińskiego w szerszym kontekście doświadczeń trzeciego pokolenia po Zagładzie, por. M. Golik Genealogia utraty. Pamięć Holokaustu w twórczości Piotra Pazińskiego i trzeciego pokolenia polskichŻydów, „Konteksty Kultury” 2019 z.1.

4 Rozmowa z Piotrem Pazińskim, "Gazeta Wyborcza" 16 czerwca 2010, http://wyborcza. pl/1,75410,8019411,Piotr_Pazinski__Istniejemy_jeszcze_jeszcze.html (dostęp: 1.08.2019).

5 Tamże.

6 P. Czapliński Zagłada i profanacje, „Teksty Drugie” 2009 nr 4, S. 202. 
przez widma przeszłości, Paziński nie opowiada wprost historii o Holokauście, podejmuje próbę uporania się z niewypowiedzianym doświadczeniem utraty i z tłumionym bólem tych, którzy owo zagrożenie czuli i których życie zostało naznaczone piętnem Zagłady. Nieprzypadkowo dzieci ocaleńców w zasadzie nie pojawiają się w jego utworach - wokół obecni są głównie starzy Żydzi, urodzeni jeszcze przed wojną, reprezentujący pokolenie dziadków, a nie rodziców. Ci ostatni nie byli w stanie znaleźć odpowiedniego języka do opowiedzenia historii własnymi słowami.

Paziński odpowiada tylko za siebie, na własną rękę próbuje pokonać ból, który, jak przekonywał Jacek Leociak, „wytrąca nas z rutyny dnia powszedniego i pozwala doświadczyć granic cielesności. Prowadzi nas nad krawędź, za którą jest już tylko groza śmierci i budzący przerażenie trup. Słowo przeradza się w krzyk, bełkot, skowyt"7. Na przekór wszystkiemu, daje się on komunikować, a wywołana przezeń trauma - przekazywać innym uczestnikom życia wspólnoty. Zdaniem Leociaka, w obliczu tak ogromnej liczby zapisków i wspomnień, spisanych przez Żydów w czasie wojny oraz już po jej zakończeniu, nie ma powodów, dla których poetyckie formuły filozofów mówiących o „całopaleniu sensu" (Maurice Blanchot) czy swoistym paraliżu języka miałyby kończyć dyskusję o możliwości racjonalnego dyskursu na temat Holokaustu. Badacz podkreśla, że „doświadczenia gra-

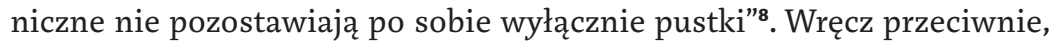
wytwarzają w podmiocie przymus dawania świadectwa, umożliwiający nie tylko współczucie jednostkom czy zbiorowości, lecz także (co nawet ważniejsze) - współdzielenie pamięci.

Tego rodzaju transfer pamięci jest konieczny zwłaszcza wtedy, gdy „słaba wspólnota"9 musi rozliczyć się z własną przeszłością i na nowo zbudować swoją tożsamość. W poprzednim wieku, jak zauważa Ryszard Nycz, podobny mechanizm zadziałał w Polsce dwukrotnie: po zakończeniu wojny oraz po transformacji

7 J. Leociak Doświadczenia graniczne. Studia o dwudziestowiecznych formach reprezentacji, Wydawnictwo IBL PAN, Warszawa 2009, s. 5.

8 Tamże.

9 A. Leder Pole symboliczne, przemieszanie, niewczesność. Humanistyka jako wybór między pamięciq̨ a nadziejq, "Teksty Drugie" 2016 nr 4, s. 247-249. Tym, co wedle Ledera odróżnia "silnych" od "słabych", ma być zdolność do odczuwania, choćby zrytualizowanej, "dumy ze wstydu". Słabe społeczeństwa, pozbawione poczucia sprawczości, wybierają jednak "dumę bez wstydu", która umożliwia uspokajające stwierdzenie: „to inni”, a w konsekwencji - pozbycie się ciążącego bagażu winy. 
ustrojowej $1989 \mathrm{roku}^{10}$. Nieumiejętność przepracowania doświadczeń skrywających wyparte poczucie winy - winy własnej bądź najbliższych, z których jedni byli ofiarami nazistowskiego totalitaryzmu, natomiast inni mniej lub bardziej biernymi świadkami rozgrywającego się wówczas dramatu" - spowodowała, że wspólnota nie potrafiła uwolnić się z zaklętego kręgu fałszywej pamięci, konstruowanej wedle heroiczno-martyrologicznego wzorca.

Przekonująco pisał na ten temat Marek Zaleski: „Polską rozkoszą jest obsadzanie się w roli ofiary. Nie tylko ofiary obcej przemocy, ale także ofiary spisku. I dziś także Polacy są ciągle zakładnikami swojej fantazmatycznej kondycji bardziej niż powinni, bo ciągle są na uwięzi swojej ciemnej jouissan$c{ }^{\prime \prime 2}$. „Przymus konstruowania zapomnienia”, który Zaleski nazywa „natręctwem niepamięci", spycha na margines pamięci wszystko, co nie mieści się w ramach wizji historii dopuszczającej jedynie opowieści o polskim bohaterstwie. Ten kompulsywnie „ponawiany rytuał dawania odporu [atakom na rzekomo zagrożone dobre imię ojczyzny - K.N.] zmienia się w patologiczny mechanizm, który paraliżuje komunikację, utrwala[jąc] syndrom ofiary"13 oraz podsycając poczucie zagrożenia ze strony Innego.

Nie ma przypadku w tym, że współczesne studia pamięciologiczne oraz badania nad Zagładą mają ze sobą tyle miejsc wspólnych - zarówno pod względem metodologii, jak poruszanych zagadnień. Wykorzystując potencjał pojęć z zakresu teorii literatury i teorii historiografii, filozofii historii, socjologii czy psychoanalizy, badacze stworzyli interdyscyplinarne zaplecze uniwersalnych rozważań o pamiętaniu, zapominaniu i traumie. Ponieważ ich znaczenie wykracza daleko poza problematykę pamięci Zagłady, nie sposób przystać na upraszczające przekonanie, by u podstaw obu dyscyplin leżało wyłącznie poczucie moralnego obowiązku wobec ofiar. Owszem, w parze z pamiętaniem, które w pewnych okolicznościach powinno przerodzić się w Ricoerowskie „fortunne zapomnienie"14, musi iść zrozumienie, że warunkiem oddania sprawiedliwości ofiarom jest wyciągnięcie wniosków i nie-

R. Nycz Polska pamięć, "Teksty Drugie” 2016 nr 6, s. 7-14.

Podział na "sprawców", "ofiary” oraz "świadków" (czy „obserwatorów”) pochodzi z fundamentalnej pracy amerykańskiego historyka Raula Hilberga: Sprawcy, ofiary, świadkowie. Zagłada Żydów 1933-1945, przeł. J. Giebułtowski, Wydawnictwo Cyklady, Warszawa 2007.

M. Zaleski Natręctwo niepamięci naszej o Zagładzie, "Teksty Drugie” 2016 nr 6, s. 92.

Tamże, s. 95.

4 P. Ricoeur Pamięć, historia, zapomnienie, przeł. J. Margański, Universitas, Kraków 2006. O koncepcji Ricoeura przypomina w artykule Natręctwo niepamięci naszej o Zagładzie M. Zaleski. 
dopuszczenie do tego, by historia zatoczyła koło ${ }^{15}$. W momencie zaistnienia, na co uwagę zwracał Andrzej Leder, Zagłada przestała być niemożliwa jako pewne zdarzeni $\mathrm{e}^{\mathbf{1 6}}$ :

Zbrodnie XX wieku się dokonały. Zdarzyła się Zagłada, zdarzył się Gułag i pola śmierci Pol Pota. Nie były konieczne, nie czekały w kolejce wydarzeń od czasu napisania przez Kartezjusza pierwszych zdań Rozprawy o metodzie, ale teraz już są. Są koniecznym wyposażeniem naszego dziedzictwa, jak każdy fakt z przeszłości. ${ }^{17}$

Skoro odtąd Zagłada, jak i inne wielkie tragedie XX wieku, jest „,koniecznym wyposażeniem naszego dziedzictwa", musimy nauczyć się o niej myśleć i mówić. Punktem zapalnym wciąż wydaje się kwestia możliwości reprezentacji doświadczenia leżącego u podstaw traumy, tzn. skonstruowania takiej opowieści o Holokauście, która - jak chciał Saul Friedländer - będąc stabilną narracją, nie odchylałaby się przesadnie ani w kierunku nadmiernej fikcjonalizacji, zagrażającej wierze w prawdziwość wydarzenia, ani estetyzacji, narażającej na szwank jego znaczenie moralne ${ }^{18}$.

Problem ten dotyczy przede wszystkim (choć nie tylko) z pozoru obiektywnych narracji historycznych. Hayden White podkreślał, iż wbrew opinii zawodowych historyków granica między dyskursem historycznym a literaturą imaginatywną nie przebiega wzdłuż linii oddzielającej prawdę od zmyślenia:

dyskurs historyczny usiłujący poznać i opisać rzeczywistość nie powinien być uważany głównie za szczególny rodzaj „wytworu naszego umysłu", ale za specjalny przypadek użycia języka, który, podobnie jak mowa

15 W tym miejscu pojawia się inny problem: jak podkreślają niektórzy badacze, istnieje ryzyko, że Zagłada, postrzegana w kategoriach jednej z największych tragedii nie tylko XX wieku, ale historii ludzkości w ogóle, przesłoni pamięć o innych ludobójstwach czy aktach zinstytucjonalizowanej przemocy. Stąd potrzeba realizowania wzorca "pamięci wielokierunkowej”, o którym w swojej fundamentalnej pracy pisał Michael Rothberg: Pamięć wielokierunkowa. Pamiętanie Zagłady w epoce dekolonizacji, przeł. K. Bojarska, Wydawnictwo IBL PAN, Warszawa 2015. H. White Zdarzenie modernistyczne, przeł. M. Nowak, w: tegoż Proza historyczna, red. E. Domańska, Universitas, Kraków 2009.

A. Leder Pole symboliczne, s. 243, 246.

H. White Prawda historyczna, wyobcowanie i niedowierzanie, przeł. E. Wilczyńska, w: tegoż Przeszłość praktyczna, red. E. Domańska, Universitas, Kraków 2014, S. 182. 
metaforyczna, język symboliczny czy przedstawienie alegoryczne, zawsze daje do zrozumienia więcej, niż mówi dosłownie, mówi coś innego niż to, co pozornie daje do zrozumienia, czy też ujawnia coś o świecie za cenę ukrycia czegoś innego. ${ }^{19}$

Takie stanowisko jest charakterystyczne dla przedstawicieli postmodernistycznej filozofii historiii ${ }^{20}$, zwłaszcza zaś jej nurtu narratywistycznego. Z rozpoznań White'a nie należy wyciągać wniosku, że przeszłość istnieje o tyle tylko, o ile jest o p o wi a d a n a, że poza narracją nie ma nic, co byłoby dostępne naszemu poznaniư ${ }^{21}$.

Kluczowym założeniem (nazwijmy je „opcją metafizyczną") - jak pisze Ewa Domańska - [...] jest przyjęcie istnienia dwóch rzeczywistości (dwóch przeszłości): obiektywnej (przeszłości rzeczywistej), istniejącej poza tekstem i poza naszą bezpośrednią percepcją, oraz rzeczywistości wykreowanej przez historyka (przeszłości historycznej), nazywanej też rzeczywistością tekstową. ${ }^{22}$

Broniąc tropologicznej teorii pisarstwa historycznego przed najczęściej wysuwanymi zarzutami (relatywizacja pojęcia prawdy, nihilizm poznawczy etc. ${ }^{23}$, White zauważa, że: „Opisy figuratywne zdarzeń rzeczywistych nie są wcale mniej «faktyczne» niż opisy dosłowne, są one jedynie faktyczne lub, jak można by to ująć, «faktologiczne» - na inny sposób". Znaczy to po prostu tyle, „że nie wolno nam mylić «faktów» ze «zdarzeniami». Zdarzenia

H. White Teoria literatury i pisarstwo historyczne, przeł. T. Dobrogoszcz, w: tegoż Proza historyczna, s. 31 .

H. White Postmodernizm i historia, przeł. E. Domańska, w: tegoż Przeszłość praktyczna, s. 35-41.

E. Domańska Biała tropologia. Hayden White i teoria pisarstwa historycznego, "Teksty Drugie" $1994 \mathrm{nr} 2$, s. 159-168.

E. Domańska Maska przeszłości (o postmodernistycznej filozofii historii), "Teksty Drugie” 1993 $\mathrm{nr} 1$, s. 108.

White pisze o tym wielokrotnie, chociażby w eseju Polityka interpretacji historycznej. Dyscyplina i de-sublimacja, w którym swój relatywizm ujmuje tak: „relatywizm jest moralnym ekwiwalentem epistemologicznego sceptycyzmu; co więcej, wierzę, że relatywizm jest podstawą tolerancji społecznej, nie zaś licencją, by »każdy robił to, na co ma ochotę«"; por. tegoż Polityka interpretacji historycznej. Dyscyplina i de-sublimacja, przeł. E. Kledzik, przekł. uzup. E. Domańska, w: tegoż Przeszłość praktyczna, s. 154, przyp. 12. 
się dzieją, fakty są ustanawiane przez opis językowy"24. Zasadnicza trudność polega na tym, jak w innym miejscu napisze autor Metahistory, że tzw. zdarzenia holokaustyczne (dwie wojny światowe, Zagłada i inne ludobójstwa, wynalezienie broni nuklearnej etc.)

wykazują niewielkie podobieństwo z tym, co wcześniej historycy zwyczajowo uważali za przedmiot swoich badań, i dlatego ich rozumienie nie może być uchwycone przez popularne techniki konwencjonalnych badań historycznych i przedstawione przez techniki pisarskie stosowane przez dziejopisarzy $[\ldots] .^{25}$

Wobec takich zdarzeń historycy są zmuszeni do stosowania „fikcyjnych technik reprezentacji"26, jakie wypracowali w swoich dziełach twórcy modernistyczni, w tym najważniejsi eksperymentatorzy XX-wiecznej literatury: James Joyce, Virginia Woolf czy Ezra Pound ${ }^{27}$. Oni zaś reagowali na postępujące w niezwykle szybkim tempie zmiany cywilizacyjne i technologiczne, którym tradycyjne formy nie potrafiły już dłużej oddać sprawiedliwości. Literatura przestała naśladować rzeczywistość (w sensie hołdowania zasadzie mimesis), ale pisarze wcale nie zaniechali szukania środków wyrazu, które pozwoliłyby ją zrozumieć; bez nich zarówno oni, jak i historycy czy filozofowie pozostaliby wobec niej bezradni.

Jeśli zastanowić się nad relacją wydarzeń historycznych do ich form reprezentacji, nie ma właściwie znaczenia, że Zagłada, stanowiąca swoisty p u n k t z e ro dla twórczości wielu artystów działających po 1945 roku, wykracza poza dostępne im doświadczenie. Jeden z bohaterów Pazińskiego w sposób dość przewrotny opisywał tę sytuację:

pan Centnerszwer chciał mnie i samego siebie utwierdzić w przekonaniu, że stanowimy jakąś jedność. Nie jedną rodzinę złączoną wspólnym

H. White Teoria literatury, s. 47.

H. White Zdarzenie modernistyczne, s. 292.

Tamże.

Według amerykańskiego historyka „stylistyczne innowacje modernizmu, zrodzone jakby z prób pogodzenia się z przewidywaną utratą specyficznego sensu historii, za którego brak modernizm jest niemal zwyczajowo krytykowany, mogą zaoferować lepsze narzędzia przedstawiania modernistycznych zdarzeń [...] niż techniki opowiadania tradycyjnie wykorzystywane przez historyków w celu prezentacji przeszłych zdarzeń istotnych dla rozwoju tożsamości danej społeczności"; H. White Zdarzenie modernistyczne, s. 308. 
losem, co byłoby jakoś zrozumiałe, ale tym samym pokoleniem, to znaczy, że ja, choć wyraźnie młodszy zostałem do nich dokooptowany i nie mam innego wyjścia, jak pogodzić się z tym stanem rzeczy. Właściwie było mi to na rękę, zaliczano mnie przecież do kręgu wtajemniczonych, stawałem się kombatantem mimo braku zasług i stażu [...] (Mieszkanie, s. 178).

Skoro „można być nostalgikiem, nigdy nie przekroczywszy progu rodzinnego domu"28, jak w swoich Formach pamięci przekonywał Zaleski, da się również przeżywać i opisywać, właśnie w trybie nostalgicznym czy melancholijnym, cudzą przeszłość i traumę ${ }^{29}$.

Podobnie rzecz ma się z odziedziczoną po poprzednikach tradycją, zwłaszcza w przypadku kogoś takiego jak Paziński. Z jego esejów o literaturze wyłania się obraz pisarza, który w pełni świadomie zaznacza miejsce swojej twórczości na mapie wpływów - to jest na szerokim pograniczu tradycji żydowskiej i modernistycznej. W tym sensie, w jakim autor Rzeczywistości poprzecieranej opowiada w swoich szkicach głównie o doświadczeniu typowym dla środkowoeuropejskich Żydów, w jego wyborach literackich nie ma nic zaskakującego. Ale wśród poetów i prozaików, do których dzieł Paziński dopisuje swoje komentarze, oprócz Brunona Schulza, Franza Kafki czy Paula Celana, znajdziemy także Jamesa Joyce'a, Jorge Luisa Borgesa i Jerzego Ficowskiego. Jak napisze we wstępie do Rzeczywistości poprzecieranej, u każdego z nich zajmuje go osobliwy i niepokojący moment, w którym: „W prześwitach ujawnia się nicość, w zdegradowanych znakach tu i ówdzie pobłyskuje ślad tego, co było"30. U Pazińskiego spojrzenie na tradycję modernistyczną (polską i żydowską) - uważne, ale nieufne - wydaje się bliskie zaproponowanemu przez Adama Lipszyca rozumieniu frankizmu jako doktryny tyleż heretyckiej, co rozszczepieńczej ${ }^{31}$. Natomiast z uwagi na historiozoficzny pesymizm

M. Zaleski Formy pamięci. O przedstawianiu przeszłości w polskiej literaturze współczesnej, Wydawnictwo IBL PAN, Warszawa 1996, s. 28.

O dziedziczeniu traumy w tym kontekście pisała Sylwia Majdosz: Pamięć i trauma dziedziczona w "Krajobrazie z dzieckiem" Romana Grena, Oskarżam Auschwitz" Mikołaja Grynberga oraz „Pensjonacie"Piotra Pazińskiego, „Politeja” 2017 nr 2.

P. Paziński Rzeczywistość poprzecierana, Austeria, Kraków-Budapeszt 2015, s. 8.

W swoich Czerwonych listach Lipszyc tak określa sytuację interesujących go autorów: „Język polski i kultura polska są właściwym żywiołem wszystkich bohaterów tej książki, żaden z nich nie pragnie więc zgłaszać akcesu do wyraziście odrębnej, odszczepieńczej tożsamości. A przecież z najróżniejszych powodów w swojej całkiem polskiej skórze nie czują się całkiem swojo. Pozostają rozszczepieni w sobie: niedopasowani, a jednak tutejsi, wyobcowani, ale nie obcy, po 
przypomina ono wzrok Benjaminowskiego anioła historii - odwrócony plecami do przyszłości, nieustannie pchany w jej kierunku dziejowym wiatrem w oglądanej przez siebie przeszłości „widzi jedną wielką katastrofę, która nieustannie piętrzy gruzy i ciska mu je pod nogi"32.

\section{2}

Bohaterowie Pensjonatu oraz Ptasich ulic próbują się odnaleźć w rzeczywistości naznaczonej taką właśnie katastrofą. Od apokaliptycznego mesjanizmu Benjamina odróżnia ją jednak to, że w prozie Pazińskiego została niemal zupełnie odarta z pierwiastka sakralnego, przez co nie można jej postrzegać w kategoriach jednego z etapów na drodze do zbawienia. Świat po katastrofie jest zupełnie inny: zrównano z ziemią kwartały ulic, zabito ludzi, którzy po nich spacerowali. Poszukującym śladów przeszłości, takim jak Mordechaj Canin, pozostała podróż „przez ruiny i zgliszcza”: „Nawet ptak nie przelatuje po niebie nad zniszczonym gettem. Nic już nie ma do oglądania w tym unicestwionym świecie. Ale odejść stąd nie sposób. Wydaje się, że każda cegła, każdy kawałek blachy wystający z pyłu woła o sprawiedliwość i domaga się uwagi"33.

Za miejsce dające choćby namiastkę poczucia bezpieczeństwa uchodzić musiał swego czasu jeden z otwockich domów wczasowych (tytułowy „pensjonat"), odwiedzany przez Żydów jeszcze przed wojną, chociaż i on, jak pokazał Cezary Rosiński, okazuje się zarażony pustką ${ }^{34}$. Intuicyjnie wyczuwają

trosze odklejeni, a zarazem na trwałe przykuci do tego, co polskie. Dlatego właśnie w swoim pisaniu próbują na rozmaite sposoby odkształcić fakturę polszczyzny, rozepchnąć ją czy rozszczepić, tak by zdołała pomieścić dziwne, nielegalne słowa, paradoksalne obrazy czy choćby puste miejsca, które mówiłyby o ich bólu, stracie, gniewie czy radości, niewyrażalnych w polszczyźnie takiej, jaką zastali i w jaką chcąc nie chcąc - wrośli. Niezadowoleni z dostępnych środków ekspresji, pokazują, że zawsze jest trochę trudniej, potworniej lub w dziwny sposób radośniej, niż to sobie dotąd mówiliśmy"; A. Lipszyc Czerwone listy. Eseje frankistowskie o literaturze polskiej, Austeria, Kraków-Budapeszt-Syrakuzy 2018, s. 9-10.

W. Benjamin O pojęciu historii, przeł. A. Lipszyc, w: tegoż Konstelacje. Wybór tekstów, przeł. A. Lipszyc, A. Wołkowicz, wstęp A. Lipszyc, Wydawnictwo U), Kraków 2012, s. 316.

M. Canin Przez ruiny i zgliszcza. Podróż po stu zgładzonych gminach żydowskich w Polsce, przeł. M. Adamczyk-Garbowska, Nisza, Warszawa 2019, s. 39. pretacji Pensjonatu Pazińskiego wspominała również Aleksandra Ubertowska w artykule Rysa, dukt, odcisk (nie)obecności. O spektrologiach Zagłady , "Teksty Drugie” 2016 nr 2. 
to także poszczególni bohaterowie miotający się między nostalgią a poczuciem beznadziei, przekonani, że nic z tego, co było dawniej, nie da się przywrócić do życia, że dla nich, polskich Żydów, nie ma już żadnej przyszłości. Wobec tego nawet filozoficzno-teologiczne dysputy panów Leona i Abrama, spierających się o istnienie i naturę starotestamentowego Boga, są jedynie mglistym wspomnieniem żarliwej wiary ich przodków. „Czas - powie narrator, a zarazem główny bohater Pensjonatu - nie zna nawrotów, a ślady przeszłości rozsypują się prędko, jak drobiny popiołu wzniecone wiatrem, lecące ku czterem krańcom niewidzialnego świata" (Pensjonat, s.48). Powróciwszy po latach do Śródborowa, otulonej sosnowymi lasami sanatoryjno-wypoczynkowej dzielnicy Otwocka, dokąd jako dziecko przyjeżdżał każdego roku wraz z babcią, w taki oto sposób opisze on swoje zajęcie: „Zdaje mi się, że wszystko, co tutaj robię, to a r c h e ol o g i a p a mi ię ci [podkr.K.N.] zapadłej w mroku jak te drzewa i jak resztki drewnianych domów. Łatwiej dojrzeć zetlały cień tego, co przeminęło, niż jutrzenkę przyszłego życia" (Pensjonat, s. 73).

Metafora archeologiczna najlepiej oddaje podstawowe założenie pisarskiego projektu Pazińskiego.Trafnie określa ona również sytuację poznawczą i egzystencjalną bohatera zmuszonego do rekonstruowania losów swoich najbliższych z fragmentów i strzępków informacji - ze zdjęć przechowywanych w zawiniątkach z gazet, z trudem odczytanych listów i pourywanych opowieści nielicznych żyjących świadków; „cały ten spektakl - jak napisze Rosiński rodzi się na styku jego pamięci i odnalezionych w budynku artefaktów"35. Tymczasem i wspomnienia, i owe „artefakty”, które na wzór Proustowskiej magdalenki wprawiają w ruch zarówno mechanizmy pamięci, jak również wyobraźnię narratora, okazują się nietrwałe. W końcu co takiego - pyta on, gdy przyjaciółka babci wręcza mu paczkę z listami i zdjęciami krewnych - „można wynieść z płonącego miasta? I dokąd zabrać? Może lepiej tego nie mieć? Pamięć ciąży jak głaz, pobudzana, nie dają jej spokojnie zasnąć" (Pensjonat, s. 21).

Skąd czerpać wiedzę o losie choćby Izaaka Feldwurma, na wpół mitycznego autora zaginionego manuskryptu powieści o Warszawie, gdy nie wiadomo, czy kiedykolwiek napisał on choć jedną linijkę wielkiej epopei, rzekomo mającej przedstawiać panoramę kilku epok z życia miasta, z setkami bohaterów i szczegółowym obrazem jego „ulic i placów, podwórek i zakamarków” ( $M a-$ nuskrypt Izaaka Feldwurma, s. 112)? Trwające wiele lat poszukiwania z konieczności przypominają fantastyczno-oniryczną podróż w głąb nieistniejącego świata - są nie tyle podróżą w czasie, ile raczej wyprawą pod podszewkę 
rzeczywistości. Tak jak Schulz kazał swojemu bohaterowi przebijać się przez nocny labirynt, gdy w migoczącym „półświetle zwielokrotniają się, plączą i wymieniają jedne z drugimi ulice”, a nawet: „Otwierają się w głębi miasta, żeby tak rzec, ulice podwójne, ulice sobowtóry, ulice kłamliwe i zwodne"36, podobnie Paziński zmusza nas, byśmy w ślad za zbiegłym Feldwurmem przyjrzeli się widmowej i nierzeczywistej Warszawie:

Mówiono, że miasto pełne jest luk i uskoków i przez nie można przedostać się w głąb, gdzie nadal kursują tramwaje, grzechocząc wesoło dzwonkami, i gdzie ludzie studiują księgi. Da się to zrobić za dnia, niekoniecznie pod osłoną nocy, trzeba tylko znaleźć odpowiednie zejście do piwnic albo starą studzienkę telefoniczną, czasem odsunąć obluzowaną cegłę czy kawałek krawężnika. Przez taką szczelinę można wśliznąć się do środka, złapać kilka garści tamtejszej mgły i zabrać ją w kieszeniach na górę. (Manuskrypt, s. 139)

Kim był wspominany w rocznicę wybuchu powstania w getcie Feldwurm? „Na co dzień Feldwurm pracował jako urzędnik w podrzędnej kancelarii adwokackiej przy Nowolipkach" (Manuskrypt, s. 105). Ambicja doprowadziła go do podjęcia rywalizacji z samym Bogiem: „ścigał się z Panem Bogiem, któremu z nich uda się zapisać więcej imion i ile z tych imion zdoła przetrwać do następnego dnia" (Manuskrypt, s. 145) ${ }^{37}$. Prosty urzędnik, który chciał zostać artystą prorokiem, od samego początku skazany na porażkę. Tym dotkliwszą, że nie ocalała ani stronica jego dzieła, a po nim samym pozostała jedynie nieustannie mutująca opowieść, apokryf pozbawiony wersji kanonicznej. Ślady jego obecności we współczesnej Warszawie są nie tylko wezwaniem do pamiętania o dawnych mieszkańcach Dzielnicy Północnej, ale i obietnicą:

Izaak Feldwurm wciąż daje o sobie znać, ostatnio jakby częściej niż dotąd. Bywa w nowych kwartałach, krąży tam dniem i nocą, nagabując ludzi, niekiedy odwiedza stare kąty i zapuszcza się w okolice dawnych dzielnic

36 B. Schulz Sklepy cynamonowe, w: tegoż Opowiadania. Wybór esejów i listów, oprac. J. Jarzębski, Ossolineum, Wrocław 1998, s. 64-65.

Abstrahując od znaczenia związanego z doświadczeniem wojennym, zapisywanie w księdze imion przywodzi w tym miejscu na myśl obchody żydowskiego Nowego Roku (Rosz ha-Szana), rozpoczynające tzw. Pokutne Dni (Jamim Noraim), które kończą się w Jom Kippur, kiedy to Bóg ostatecznie osądza ludzkie uczynki i decyduje o wpisie albo do Księgi Życia (Sefer ha-Chajim), albo do Księgi Śmierci. 
północnych. W Warszawie widziało go wielu. Niewykluczone, że każdy chociaż raz w życiu natknął się na Izaaka Feldwurma. Przepowiadają: nadejdzie czas, a zobaczą go wszyscy. (Manuskrypt, s. 146)

Feldwurm to przy tym jeden z kilku bohaterów Pazińskiego, których pochłania marzenie o Schulzowskiej Księdze. Jerzy Jarzębski pisał o niej, że jest „jednocześnie światem, prototypem wszystkich książek - a więc mitów i literatury, jest także lustrem, w którym przegląda się każda ludzka istota, wciela obecne w niej pragnienie ładu" ${ }^{\text {"38 }}$. Ten motyw powraca także w innych miejscach. Bohater opowiadania Staruszek, nie mogąc skontaktować się z niewidzianym od kilku dni sąsiadem, panem Wilfem, planuje odnaleźć jego numer w przedwojennej książce telefonicznej. W „zaprzyjaźnionym antykwariacie" znajduje egzemplarz, jak mu się wydaje, należący właśnie do Wilfa. Gdy w domu zaczyna wertować kupioną książkę, przez antykwariusza reklamowaną jako "prawdziwy biały kruk", orientuje się, że wcisnął mu on zaledwie "nędzny reprint, wybrakowany, zawierający może dwie trzecie oryginalnych haseł, znacznie cieńszy od pierwowzoru, bez początku i końca, w dodatku z poprzestawianymi szpaltami, złożony na nowo, żeby nie było widać białych plam po ingerencjach wydawcy" (Staruszek, s. 94). Podobnie jak małemu Józefowi, tak i jemu cudza ręka podsunęła jedynie „skażony apokryf, tysiączną kopię, nieudolny falsyfikat"39. Księgę przypomina też przygotowywany przez pana Abrama słownik biograficzny wszystkich Żydów, skrupulatnie zapisywany „na biletach tramwajowych i kolejowych, na kwitach z pralni i na marginesach gazet" (Pensjonat, s.42). Projekt w równej mierze ambitny, co szalony, wynikający z wiary w to, że „Księga jest postulatem, że jest zadaniem” ${ }^{40}$.

\section{3}

Nie tylko w sposobie kreowania postaci oraz świata przedstawionego, ale również w samej strukturze „narracji metafizycznych” Pazińskiego (określenie Jana Gondowicza) daje się zauważyć wyraźne napięcie między doświadczeniem historycznym, pamięcią i problemem ich reprezentacji w tekście. W recenzji z Ptasich ulic Andrzej Skrendo przekonywał, że odejście od ściśle

\footnotetext{
38 J. Jarzębski Wstęp, w: B. Schulz Opowiadania, s. LXXXVIII.

39 B. Schulz Księga, w: tegoż Opowiadania, s. 117.

40 Tamże.
} 
realistycznego obrazowania oraz pozbawienie prozy spójnego, linearnego przebiegu fabularnego odgrywa tutaj niezwykle istotną rolę. Zestawiając opowiadania ze wspomnianego tomu z prozą Schulza oraz Wszystko jest iluminacją Jonathana Safrana Foera (również należącego do trzeciego pokolenia), badacz tak uzasadniał celowość rezygnacji z formy powieściowej na rzecz zbioru krótkich fabuł: „fragmentów roztrzaskanego świata - powiada Skrendo - nie sposób ułożyć w spójną epicką narrację. I odchodzący (wraz ze śmiercią ostatnich świadków Zagłady) świat istnieje w wielu wersjach równocześnie. Funkcjonuje tak jak pamięć: jest nieciągły, poszarpany, niepewny i wieloraki"41.

Narrator prozy Pazińskiego nieustannie występuje przeciwko nieciągłości zarówno pamięci, jak historii. Pensjonat rozpoczyna wymowne powtórzenie pierwszych słów Tory - „na początku” (hebr. bereszit) - które w innych okolicznościach, przed katastrofą, mogłoby pewnie stanowić fundament dla spójnej opowieści. Odwołanie do pozaczasowego porządku wskazuje wprawdzie na ważną dla Pazińskiego tradycję religijną, ale w odczarowanym, odartym z boskości świecie nie ma żadnej mocy sprawczej. Zwłaszcza że najważniejszym punktem odniesienia dla opisywanych wydarzeń narrator zarówno Pensjonatu, jak opowiadań z Ptasich ulic czyni przecież swoje przygodne i nietrwałe wspomnienia ${ }^{42}$. Nostalgiczne usposobienie głównego bohatera prozy Pazińskiego sprawia, że powieściowe „tu i teraz” zawsze przegrywa z wyidealizowanym obrazem przeszłości. Z jej obrazem, nie zaś z nią samą, ponieważ każda przeszłość - by przypomnieć słynną formułę Davida Lowenthala - „to jest obcy kraj”. To, co „dziś uchodzi za przeszłość - pisał amerykański historyk - nigdy w takiej postaci nie było postrzegane jako teraźniejszość przez ludzi tę przeszłość zamieszkujących"43. Stąd wraz z upływem czasu, potęgującym tylko melancholijną dyspozycję narratora, wzmaga się bolesne doświadczenie obcości:

Niewiele więcej pamiętam. Chwilami tyle co nic. Moja przeszłość tkwi we mnie głęboko, lecz kiedy staram się do niej dotrzeć, natrafiam na wydrążoną pustkę, jakbym urodził się wczoraj, a wszystko, co dawniej się wydarzyło, było tylko gąszczem cienistych obrazów, zetlałych

41 A. Skrendo Rzeczywistość wzmożona, "Tygodnik Powszechny” 2013 nr 43, www.tygodnikpowszechny.pl/rzeczywistosc-wzmozona-20859 (dostęp: 28.05.2019). 
i rozsypanych w drobiny atomów, o których opowiadał pan Leon. Natłok tych obrazów stwarza iluzję pamięci i podobnie jak mnogość fotografii staje się namiastką życia. [...] I dzisiaj już wiem, że stamtąd, z tamtej jadalni bierze się stale mi towarzyszące poczucie życia na wyspie, nieadekwatności czy niedopasowania. (Pensjonat, s. 103)

Paziński uprawia w swoich utworach z ducha modernistyczną „archeologię pamięci", polegającą na ciągłym odgrywaniu scen powrotu do czasów dzieciństwa, ale wbrew pozorom nie ma ona wiele wspólnego z obietnicą spełnienia "genialnej epoki” oraz nadejścia „czasów mesjaszowych", które - jak w jednym z listów pisał Schulz - „nam przez wszystkie mitologie są przyrzeczone"44. A przecież ideał „dojrzewania do dzieciństwa”, przy pewnej korekcie mogący oznaczać również dojrzewanie do przeszłości oraz zdolność przepracowania traumy przekazywanej bohaterowi poprzez milczenie ocalałych, dawałby jeszcze jakąś nadzieję na fortunną przyszłość. Z tym że w przeciwieństwie do autora Sklepów cynamonowych, z którego twórczości czerpie rozmaite motywy i schematy fabularne, autor Ptasich ulic zdaje się nie wierzyć, że wyobraźnia pozwala powtórnie osiągnąć właściwą dziecku niewinność oglądu świata.

Dzieciństwo bohatera Pensjonatu upłynęło wprawdzie w sielankowej scenerii otwockiego domu wczasowego, lecz wśród ludzi pogrążonych w żałobie, pozbawionych wiary w przyszłość. Mimo że to okruchy szczęśliwych wspomnień stanowią fundament całej opowieści, sam akt opracowywania pewnego wyobrażenia przeszłości nie przynosi mu żadnego pocieszenia zupełnie jakby żyjący „iluzją pamięci” narrator nie tylko nie był w stanie pogodzić się z nawiedzającymi go widmami, ale też nie potrafił sprostać etycznej powinności, do jakiej został zobowiązany przez tych, którym udało się ocaleć. „Ostatni z łańcucha pokoleń, uczepiony na samym końcu” - powiada $\mathrm{w}$ przedostatnim zdaniu powieści, w finale epifanicznej sceny spotkania z duchami zmarłych przodków i przyjaciół rodziny. Tuż przed ucieczką: „Była głęboka noc, gdy dotarłem na stację" (Pensjonat, s. 135).

\section{4}

Literatura nie pozwala zapomnieć ani uciec od przeszłości. Równocześnie - i to w kontekście twórczości Pazińskiego chyba najistotniejsze - daje 
możliwość wykorzystania wydarzeń historycznych do stworzenia zupełnie nowej opowieści, która ze względu na obecność pierwiastka fikcyjnego przenosi dyskusję w obręb rozważań o literaturze. Dylematy dotyczące prawdziwości narracji o Zagładzie zostają w ten sposób niejako odsunięte na dalszy plan - chodzi bowiem nie o to, co wydarzyło się naprawdę, lecz o pewną wizję czasów minionych, która zresztą nie rości sobie takich pretensji. Upominając się o żydowską przeszłość, Paziński siłą rzeczy konfrontuje się z dominującym w ramach naszej wspólnoty obrazem historii poprzedniego wieku, robi to jednak w sposób przywodzący na myśl Rothbergowski projekt pamięci wielokierunkowej, dopuszczającej równorzędne (nie na zasadzie „rywalizacji form”) traktowanie pamięci różnych grup - społecznych, etnicznych czy religijnych.

W twórczości Pazińskiego ważną rolę mają do odegrania także przepuszczone przez filtr wyobraźni Schulza oraz Borgesa metafory: „księgi”, „biblioteki” oraz „ogrodu”, zgodnie z którymi świat postrzegany jest w kategoriach tekstu - tajemniczego i paradoksalnego, zarazem skończonego i nieskończonego, bo podlegającego ciągłym zmianom, rozgałęzieniom, mutacjom ${ }^{45}$. Istnienie pewnych alternatywnych wersji zdarzeń, jak choćby w analizowanym wcześniej opowiadaniu o Feldwurmie, nie tylko odsyła czytelnika do całego szeregu innych opowieści, zwracając uwagę na intertekstualność literatury oraz nieskończoność procesu interpretacji, ale sugeruje jednocześnie występowanie pewnego prześwitu między światem zapisanym/zapamiętanym a dostępną naszym zmysłom rzeczywistością. Prześwitu, który ze względu na swój graniczny charakter, na swoiste uwikłanie w oba porządki (fikcjonalny i faktualny, literacki i empiryczny), domaga się tyleż uważnego namysłu, co drobiazgowej lektury. Paziński bowiem, co doskonale widać na przykładzie jego esejów, myśli o poznawaniu otaczającej go rzeczywistości jako o formie literackiej egzegezy. Toteż jeżeli gdzieś szuka fundamentu dla swoich opowieści, to nie tylko w historii czy własnej pamięci, ale również w szeroko pojętej tradycji. Ze szczególnym uwzględnieniem tych twórców (jak Kafka, Borges, Schulz, Celan, Agnon czy Joyce), dla których świat i literatura znaczą w zasadzie jedno i to samo, a refleksja metaliteracka nieodmiennie wiąże się w ich dziele z rozważaniem problemów z pogranicza teologii, metafizyki czy filozofii historii. Im to Paziński zawdzięcza przekonanie, że w odczarowanym świecie jedyną rzeczą, która się ostaje, jest literatura (co nie znaczy, że ma ona nieograniczoną czy ocalającą moc). 
Spośród innych autorów zarówno drugiego, jak i trzeciego pokolenia po Holokauście Pazińskiego wyróżnia bodaj przede wszystkim nieoczywistość inspiracji określających jego horyzont zainteresowań, sięgający od judaizmu po szeroko pojętą tradycję moderny ${ }^{46}$. O ile w ich dziełach stawką, o jaką toczy się gra, wydaje się przede wszystkim rekonstruowanie własnej tożsamości oraz próba udzielenia odpowiedzi na pytanie, co dziś znaczy być Żydem, o tyle u niego widać fascynację sło w e m (jako nośnikiem śladów tego, co nieskażone, co zatem mogłoby pochodzić jeszcze z czasów sprzed katastrofy) oraz możliwościami, jakie zapewniają literackie mechanizmy produkowania znaczeń $^{47}$. W przeciwieństwie do Agaty Tuszyńskiej z jej Rodzinną historią lęku czy Marcina Wichy i jego niedawno wydanych Rzeczy, których nie wyrzuciłem autora Rzeczywistości poprzecieranej dochodzenie do własnej żydowskości właściwie nie zajmuje, jako że nigdy nie była to tradycja przed nim ukrywana, a przez to owiana aurą tajemnicy. Głęboko odczuwane poczucie wywłaszczenia, a także ból po stracie bliskich osób czy miejsc, z którymi jako pisarzowi przychodzi się Pazińskiemu mierzyć, nie stają się przez to wcale mniej dotkliwe. Być może łatwiej mu jedynie, dzięki temu, że znalazł dla swoich doświadczeń teologiczny czy literacki kontekst, uczynić z nich źródło własnej opowieści.

Podobnie jak Penelopa, która w jednym z wierszy Aleksandra Wata „zna sekret: / że trzeba tkać i pruć. I znowu tkać i pruć" "48, Paziński zdaje się wierzyć, że jedynym ratunkiem jest opowiadanie czy przepisywanie na nowo już raz opowiedzianych historii. Nieprzypadkowo zatem wszystkie teksty pomieszczone w Ptasich ulicach stanowią w zasadzie wariację na jeden i ten sam temat: śmierci - począwszy od Konduktu, którego akcja dzieje się na cmentarzu w czasie uroczystości pogrzebowej bliżej nieznanego mężczyzny, przez dwa opowiadania wspomniane wcześniej, a skończywszy na zamykającej tom prozie Mieszkanie, której bohater został wezwany do wzięcia udziału w tradycyjnym czuwaniu przy zwłokach zmarłej doktor Kamińskiej, dawnej przyjaciółki rodziny. To by z kolei stawiało autora Ptasich ulic, a także niektórych jego bohaterów, w roli przypominającej żydowskiego skrybę z przypowieści

46 Nie chcę przez to powiedzieć, że są to tradycje zasadniczo od siebie różne, dla których nie sposób znaleźć miejsc wspólnych, lecz podkreślić istotną rozbieżność między myśleniem teologicznym a świeckim czy też, mówiąc inaczej, między Jerozolimą a Atenami. Por. A. Bielik-Robson Erros. Mesjański witalizm i filozofia, Universitas, Kraków 2012. kauście, przeł. I.J. Barry i in., Austeria, Kraków-Budapeszt 2013.

48 A. Wat Poezje zebrane, oprac. A. Micińska, J. Zieliński, Wydawnictwo Znak, Kraków 1992, s. 215. 
Agnona - tego, który nie tylko stoi na straży tradycji przepisywania świętych tekstów, ale stara się również „odcisnąć w pamięci” (Kondukt, s. 13) losy tych, którzy powoli odchodzą lub już odeszli z tego świata ${ }^{49}$.

\section{Abstract}

\section{Kamil Nolbert}

UNIVERSITY OFWROCŁAW

Reality Remembered: History and Memory of the Shoah in Piotr Paziński's Fiction

Nolbert inscribes the work of Polish writer Piotr Paziński (b. 1973) in the broader context of post-memory literature as well as the interdisciplinary debate on possible forms of representing the Shoah in art. Drawing on scholars such as Hayden White he explores the tension, palpable in Paziński's works, between history and individual/collective memory. Nolbert also discusses how this tension shapes the represented universe, the protagonists and the very structure of the text.

\section{Keywords}

Piotr Paziński, Holocaust, Shoah, memory, history, trauma

49 Por. S.J. Agnon Przypowieść o skrybie, w: tegoż Przypowieść o skrybie i inne opowiadania, wyb. i przeł. P. Paziński, Nisza, Warszawa 2016. 